\title{
A Critical Assessment of the Pollution Prevention Laws and Regulations of Nigeria: Why They Failed to Protect the Environment of Nigeria
}

\author{
Noah A. Izoukumor \\ University of the West of England Coldharbour Ln, Stoke Gifford, Bristol BS16 1QY
}

\begin{abstract}
The research is financed by Chief Favour O. Izoukumor (The Fieye-Owie of Ogbe-Ijoh Warri Kingdom, the immediate past commissioner representing Ijaw Ethnic Nationality on the board of DESOPADEC)

Abstract

Oil pollution is a big challenge to the Nigerian government. The National Oil Spill Detection and Response Agency claimed that from January 2010 to August 2015, about 294,352 barrels of oil spilled into the Niger Delta environment of Nigeria. The truth is that the Nigerian government initiated several policies, laws, regulations and standards to curb crude oil pollution in the Niger Delta area of Nigeria, still, pollution is on the increase. This article seeks to critically assess the weaknesses of the pollution prevention laws and regulations set up by the Nigerian government to protect and prevent oil pollution in the Niger Delta area of Nigeria. The analyses of this article show that the penalties imposed on the Oil Corporation to clean up oil spill are too low, enforcement of the laws is exclusively placed on the Attorney General of the Federal Republic of Nigeria while excluding public litigation, inspection of oil pipelines is imposed on the operators while allowing the regulators to sleep. To surmount these challenges, this article concludes that the regulators in the oil sector should take responsibility of investigating and monitoring the activities of the operators, there should be stringent sanction compelling the operators to clean-up oil spill whenever it occurs.
\end{abstract}

Keywords: Environment, Laws, Regulations, Pollution, Oil Spill, Nigeria

DOI: $10.7176 / \mathrm{JLPG} / 87-06$

Publication date:July $31^{\text {st }} 2019$

\section{Introduction}

Nigeria is one of the major crude oil producers and polluters, ${ }^{1}$ and the consequence of pollution to the immediate environment ranging from oil spills, dumping of toxic waste materials by the International Oil Companies has already been felt and seen by the people. The official data of the National Oil Spill Detection and Response Agency reports that from January 2010 to August 2015 there were 6333 oil spills in the Niger Delta area of Nigeria, about 294,352 barrels of oil spilled into the Niger Delta environment. ${ }^{2}$ This has already affected the people's health, the sources of their drinking waters and a massive decline of the biodiversity, especially, in the Niger Delta area of Nigeria. ${ }^{3}$

To arrest environmental pollution, the Nigerian government launched her first environmental policy known as the National Policy on Environment in 1989. ${ }^{4}$ The National Policy on Environment was reviewed and revised in 1999. One of the goals of the National Policy on Environment is to ensure that the environment is protected from pollution and make it suitable for the well-being of all Nigerians. ${ }^{5}$ Similarly, the Nigerian governmentinitiated Vision 20:2020 (NV20:2020) in 2009, which point to the protection of the environment. NV20:2020 is a blueprint of economic transformation of Nigeria targeted for eleven years, that is, from 2009-2020. It incorporates protection of the environment which is one of the key objectives to achieve before 2020. Some of the specific objectives outlined in NV20:2020 is to "reduce the occurrence and impact of environmental hazards. ${ }^{6}$ This includes reduction of land and water pollution of any kind. Just about a year to the expiration of the NV20:2020, the realization of these goals, that is, protection of the environment from pollution is uncertain.

\footnotetext{
1 'Gas Flaring in Nigeria: A Human Rights, Environmental and Economic Monstrosity' (Friends of the Earth International 2006) $<$ http://www.foei.org/resources/publications/publications-by-subject/climate-justice-energy-publications/gas-flaring-in-nigeria > accessed 30 July 2016

2 'Improving Oil Spill Response in Nigeria-Comparative Analysis of the Forms, Data and Related Process of the JIV' (Stakeholder Democracy Network 2016) 31 < http://www.stakeholderdemocracy.org/improving-oil-spill-response-in-nigeria-comparative-analysis-of-theforms-data-and-related-processes-of-the-joint-investigation-visit-jiv-and-suggestions-on-how-these-could-be-improved/> accessed 30 July 2016

${ }^{3}$ Environmental Assessment of Ogoniland' (United Nation Environmental Programme 2011) 37-45<http://www.unep.org/> accessed 12 July 2016

4 'Review of the National Policy on the Environment 1999' (Federal Ministry of Environment 2014)http://environment.gov.ng/index.php/downloads/3-environmental-policies accessed 28 July 2016

${ }^{5}$ Ibid; Most importantly, the NPE outlined the means of achieving this goal, it encourages the government to develop laws, establish Agencies and structures in order to achieve the objectives of this Policy

6 'Report of the Vision 2020 National Technical Working Group on Environment and Sustainable Development' (Federal Ministry of Budget and National Planning 2009) $26<$ http://www.nationalplanning.gov.ng/index.php/national-plans/nv20-2020> accessed 26 July 2016
} 
As the National Technical Working Group (NTWG) of Vision NV20:2020 identified 'pollution control', and 'weak environmental governance' are some of the challenges in Nigeria. ${ }^{1}$

Apart from the policies, the Nigerian government signed more than 24 environmental related treaties, ${ }^{2}$ enacted more than 27 environmental protection laws, ${ }^{3}$ including 27 subsidiary regulations ${ }^{4}$ specifically for the protection of the environment, yet pollution is on the increase. Whether or not an environment is healthy or pollution free is dependent on the policies, the substantive laws and the regulations initiated by the government to protect the environment. ${ }^{5}$ In this sense, this piece critically analyses primarily, the weaknesses of the substantive laws and subsidiary legislation made by the Nigerian parliament to protect the environment with particular attention to oil pollution. The following issues are analysed, the penalties imposed on the operators, ${ }^{6}$ who can bring an action in court to enforce the laws, the shifting of inspection role of pipelines by the regulators ${ }^{7}$ to the operators and the restriction of the public from instituting legal action against polluters.

\section{The substantive laws enacted by Parliament to Protect the Environment from Pollution}

All substantive laws made by the Nigerian parliament to protect the environment are designated as an Act, ${ }^{8}$ while those delegated by the parliament is referred as regulation. ${ }^{9}$ The reason for regulation is that parliament may not foresee and include all the essentials during legislation. Hence, ministers appointed in petroleum sector sometimes are empowered to make regulations to protect the environment. ${ }^{10}$

The starting point of the substantive laws enacted for the protection of the environment of Nigeria could be traced to the incorporation of Article 24 of the African Charter in 1982, ${ }^{11}$ which was ratified by the Nigerian parliament in $1983 .{ }^{12}$ Art. 24 of the African Charter declares that all Nigerians shall have the right to a general satisfactory environment favourable to their development. This provision triggered the quest for the protection of the Nigerian environment by activists as it forms the source of the popular case, Social and Economic Rights Action Centre v. Nigeria. ${ }^{13}$ In this case, the complainants alleged inter alia that the Federal government of Nigeria involved in reckless production of crude oil in Ogoni Land (a community in the Niger Delta area of Nigeria) and that the reckless activities had damaged the lands. ${ }^{14}$

Also, the Constitution of the Federal Republic of Nigeria (CFRN) strongly directs the Nigerian government to protect the environment. Though, protection of the environment was not provided for in the Nigerian constitution before $1999 .{ }^{15}$ But when the 1999 Constitution was drafted, section 20 of the constitution imposed an obligation on the government to protect and improve the environment particularly the land, water, and air. ${ }^{16}$ The phrase to 'protect and improve' used by section 20 of the constitution literarily imposed an obligation on the legislature to make new laws and improve on the existing rules to protect the Nigerian environment from all kind of pollution. This provision of the constitution has been fulfilled as the Nigerian parliament enacted series of environmental protection laws. ${ }^{17}$ The most relevant laws enacted by the Nigerian parliament in relation to this piece of work are the National Oil Spills Detection and Response Act, ${ }^{18}$ Oil Pipelines Act, ${ }^{19}$ the Petroleum Act, ${ }^{20}$ which is about to be amended by the Petroleum Industry Bill, ${ }^{21}$ the Oil Navigation Act, ${ }^{1}$ Environmental Impact

\footnotetext{
${ }^{1}$ Ibid 9-10

${ }^{2}$ Musa Ibrahim and Kasim Imam, 'Overview of Environmental Laws, Regulations, And Multilateral Environmental Agreements in Nigeria' (UNEP Global Training Programme on Environmental Law \& Policy 5th - 13th October 2015 Nairobi, Kenya)

${ }^{3}$ Environmental Law Research Institute, <http://www.elri-ng.org/newsandrelease2.html> accessed 4 July 2016

${ }^{4}$ Musa Ibrahim and Kasim Imam (n-8) see also, Eneh, Onyenekenwa C and V. C. Agbazue, 'Protection of Nigeria's environment: A critical policy review' [2011] 4 (5) Journal of Environmental Science and Technology 490-497

${ }^{5}$ Ajugwo, Anslem O, 'Negative effects of gas flaring: The Nigerian experience' [2013] 1(1) Journal of Environment Pollution and Human Health 6-8

${ }^{6}$ The operators used here is referred to the International Oil Companies (IOCs)

${ }^{7}$ The regulators used here are the Agencies legally empowered to enforce the laws on the IOCs

8 'Restoring Nigeria's Law to Nigeria's People - One by One' (Centre for Laws of the Federation of Nigeria) $<$ http://lawnigeria.com/FederationlawsN.html $>$ assessed 3 June 2016 9 ibid

${ }^{10}$ Section 33(c) of the Oil Pipeline Act empowers the minister to make subsidiary regulations to prevent pollution of the land and the water. Based on this power the minister in 1995 established the Oil and Gas Pipelines Regulation; see also section 14 of the Oil and gas pipelines regulation Cap O7 LFN 2004

${ }^{11}$ Organization of African Unity (OAU), African Charter on Human and Peoples' Rights ("Banjul Charter"), 27 June 1981, CAB/LEG/67/3 rev. 5, 21 I.L.M. 58 (1982), available at: http://www.refworld.org/docid/3ae6b3630.html [accessed 2 September 2016]

${ }^{12}$ African Charter on Human and Peoples' Rights (Ratification and Enforcement) Act - CAP. A 9 L.F.N. 2004

${ }^{13} 155 / 96$ Social and Economic Rights Action Center (SERAC) and Center for Economic and Social Rights (CESR) / Nigeria

${ }^{14}$ Ibid See paragraph 9

${ }^{15} \mathrm{C}$ T Emejuru, 'Human Rights and Environment: Whither Nigeria? ' [2014] 30(2224) Journal of Law, Policy and Globalization 19-27

${ }^{16}$ Emphasis added

${ }^{17}$ Environmental Law Research Institute, <http://www.elri-ng.org/newsandrelease2.html> accessed 4 July 2016

${ }^{18}$ National Oil Spill Detection and Response Agency, (Establishment) Act, 2006

${ }^{19}$ Oil Pipeline ActCAP. O7 L.F.N. 2004

${ }^{20}$ Petroleum Act CAP. P10 L.F.N. 2004

${ }^{21}$ The Petroleum Industry Bill 2012, (Federal Republic of Nigeria National House of Assembly) < http://www.nassnig.org/ > assessed 20
} 
Assessment Act ${ }^{2}$ and the Freedom of Information Act. $^{3}$

The National Oil Spills Detection and Response Act was enacted by the Nigerian parliament to implement the National Oil Spill Contingency Plan. ${ }^{4}$ National Oil Spill Contingency Plan is a document designed by the federal government of Nigeria which specifies the role of the federal government to curtail oil spill incidents and protect the environment. ${ }^{5}$ Section 7(d) of the National Oil Spills Detection and Response Act empowers the National Oil Spill Detection and Response Agency---an established body under the Act ${ }^{6}{ }^{\circ}$ to prevent, control, combat and mitigate marine pollution. ${ }^{.7}$ The National Oil Spills Detection and Response Act penalizes a polluter who refuses to report oil spill incidents, ${ }^{8}$ while refusal to clean up spills attracts penalties. ${ }^{9}$

Section 17(4) of the Oil Pipeline Act ${ }^{10}$ states that an operator who is granted a licence to operate pipelines is under an obligation to prevent pollution on the land and the water. The Oil Navigation $\mathrm{Act}^{11}$ was mainly enacted to prevent pollution in the sea. ${ }^{12}$ Section 1 of the Act, specifically prohibits pollution of the environment by crude oil, it criminalises a vessel owner who discharges crude oil into the waters and prohibited area of the sea. Failure to comply with the provision of the Oil Navigation Act attracts fines. ${ }^{13}$

The Environmental Impact Assessment Act $^{14}$ provides that construction of projects in relation to pipelines exceeding 50 kilometres in length should only be carried out if authorised by the authority responsible for environmental impact assessment. ${ }^{15}$ The Freedom of Information Act in a bit to protect the environment demands public institutions to make information available to the public. ${ }^{16}$ This includes oil pollution records which will enable the public especially, those who might be affected by oil activities to institute an action in court to protect the environment. ${ }^{17}$

\section{Subsidiary Laws made by Ministers to Protect the Environment}

As earlier stated, the parliament most times delegates its primary obligation of making laws to ministers to make specific laws for the protection of the environment. Large number of legal instruments for the protection of environment especially crude oil are being made through delegation. Section 33(c) of the Oil Pipeline Act empowers the minister to make subsidiary regulations to prevent pollution of the land and the water. Based on this power the minister in 1995 established the Oil and Gas Pipelines Regulation. ${ }^{18}$ This regulation imposes an obligation on the Oil Corporations to design a contingency plan to prevent pollution, ${ }^{19}$ and failure to comply with the regulation attract a fine or an imprisonment term of six months. ${ }^{20}$

Section 27 of the Petroleum Refining Regulation prohibits disposal of petroleum product in any other manner than places approved under the law. Failure of an operator to comply with this regulation is 'liable on conviction to a fine or imprisonment for a term of six months. ${ }^{21}$ A Similar provision is contained in the Oil in the Navigable Waters Regulations 1968, ${ }^{22}$ Petroleum (Drilling and Production Regulations 1969, ${ }^{23}$ Petroleum Drilling and Production (Amendment) Regulations 1973, ${ }^{24}$ and Petroleum Refining Regulations 1974. ${ }^{25}$

Most specific and comprehensive regulation is the Environmental Guidelines and Standards for the Petroleum Industry in Nigeria (EGASPIN). Part VI, A, 2.0 of EGASPIN provides that the Oil Corporations should report oil spills and control such spill 'to minimize impacts on human health, other living organisms, and

August 2016

${ }^{1}$ Oil in Navigable Waters Act - CAP. O6 L.F.N. 2004

${ }^{2}$ Environmental Impact Assessment Act - CAP. E12 L.F.N. 2004

${ }^{3}$ Freedom of Information Act, 2011

${ }^{4}$ The National Oil Spill Contingency Plan [NOSCP] (Revised May 2009)

${ }^{5}$ The National Oil Spill Contingency Plan [NOSCP] (Revised May 2009) Paragraph 2.1

${ }^{6}$ National Oil Spill Detection and Response Agency, (Establishment) Act, 2006 Section 1(1-2)

${ }^{7}$ Ibid See section 7 (c) and (d)

${ }^{8}$ Ibid Section 6(2)

${ }^{9}$ Ibid Section 6(3); see also section 245 and 247 (a) of the Criminal Code CAP. C38 L.F.N. 2004 Section 243-248 which forbids any person from contaminating the atmosphere that will be detrimental to the health of the general public

${ }^{10}$ Oil Pipeline Act CAP. O7 L.F.N. 2004

${ }^{11}$ Oil in Navigable Waters Act - CAP. O6 L.F.N. 2004

${ }^{12}$ Ibid See the Preamble of the Oil Navigation Act

${ }^{13}$ Ibid Section 7 (5) a

${ }^{14}$ Environmental Impact Assessment Act - CAP. E12 L.F.N. 2004

${ }^{15}$ Ibid Section 13 and First Schedule Mandatory Study Activities item 12

${ }^{16}$ Freedom of Information Act 2011, Section 1

${ }^{17}$ Ibid

${ }^{18}$ Oil and gas pipelines regulation Cap O7 LFN 2004 see section 14

${ }^{19}$ The Oil Pipelines Regulation Section 9 (1) (b)

${ }^{20}$ Ibid Section 26

${ }^{21}$ Petroleum Refining Regulation Section 45 (1) and (2); see also, The Associated Gas Re-Injection Act Cap 26 LFN 1990 ; Cap A. 25 LFN

2004; see also, section 1 The Associated Gas Re-Injection (Continued Flaring of Gas) Regulations SI 43 of 1984 , Cap A25 LFN 2004

${ }^{22}$ See section 2 and 5 of the Oil in the Navigable Waters Regulations 1968 CAP. O6 L.F.N. 2004

${ }^{23}$ Section 25establishes that reasonable measures be taken to prevent water pollution

${ }^{24}$ Petroleum Drilling and Production (Amendment) Regulations 1973, CAP. P10 L.F.N. 2004

${ }^{25}$ Section 43 (3) of Petroleum Refining Regulations 1974, CAP. P10 L.F.N. 2004 
properties.' ${ }^{1}$ It further instructs the Oil Corporations to take precautionary measures to prevent pollution. ${ }^{2}$

\section{Analysis of the weaknesses of the substantive laws and the regulations}

As already stated above, there are more than 27 subsidiary regulations initiated by the Nigerian government to protect the environment. ${ }^{3}$ Despite the laws enacted by the parliament or the regulation made by the ministers to protect the environment, oil pollution in the Niger Delta area of Nigeria is on the rise. Below are some of the reasons why pollution is still on the rise irrespective of the presence of the laws, policies and the regulations.

\subsection{Penalties Imposed on the Oil Corporations are too small}

It has been warned that the penalties imposed on the operators are too low and it is easier for the operators to pay and continue with bad practices. ${ }^{4}$ For instance, The Oil Navigable Waters Act particularly section 10 (1) and (2) states that an owner of a vessel is liable for a summary conviction to a fine not exceeding N400 if the owner refuses to report an escape of oil from a vessel which pollutes the water. ${ }^{5}$ A similar provision is contained in the National Oil Spills Detection and Response Act. Section 6(2) of the Act penalizes a polluter who refuses to report oil spill incidents to pay a fine of N500, 000 .

The above sanctions of N400 and N500, 000 imposed by the Oil Navigation Act and National Oil Spills Detection and Response Act in the current exchange rate are about $£ 1$ and $£ 1000$ respectively. This is too low for the Oil Corporations. ${ }^{6}$ In contrast, the Oil Pollution Act $1990^{7}$ of the United States of America (USA) which was amended in 2010 has increased liability to $\$ 1.5$ billion. The Oil Pollution Act of USA does not just increase sanction but impose liability for a party that causes the pollution to clean up the affected environment, and the liability imposed by the law is commensurate to the size and the location of the spill. For instance, the liability of a spill of 3,000 gross tons is expected to incur $\$ 10,000,000$, if it is offshore, the liability is $\$ 1.5$ billion. ${ }^{8}$

Unlike the Oil Navigation Act which demands mere payment of sanction without imposing an obligation to clear up the polluted areas. Supposing an area is polluted by an operator due to negligence and a sanction of $£ 5$ million was imposed as a penalty if the operator pays the penalty without doing more will leave the damaged environment causing harm to human. If this is the case, then the purpose of the law is being defeated. Therefore, the penalties recognised in the Oil Navigation and the National Oil Spills Detection and Response Acts should be reviewed and this should go along with a liability of removing whatever contamination deposited on the environment. Though, the National Oil Spills Detection and Response Act recognises the need to clean up a polluted site. ${ }^{9}$

\subsection{Obligation Imposed on Attorney General of Federation to bring Court Action against Polluters}

The Oil Navigation Act vests an obligation on the Attorney General of the Federation ${ }^{10}$ to bring an action in court against a polluter who destroys the environment. Any other affected person must do so with the consent of the Attorney General of the Federation. ${ }^{11}$ One of the disadvantages of this provision is that the Attorney General of the Federation may not bring an action against government-owned corporations and enforce compliance, especially, in Nigeria where government corporation is among the polluters. ${ }^{12}$ Since the Attorney General of the Federation is an employee of the Federal Government he will be reluctant to bring an action against his employer. This was the case when Nigeria National Petroleum Corporation (NNPC) - a Nigerian Government Corporation's pipeline erupted and polluted Ineh and Aku streams in the Niger Delta. ${ }^{13}$ Failure on the part of the

\footnotetext{
${ }^{1}$ Environmental Guidelines and Standards for the Petroleum Industry 2002 Revised; PART VIII, A, 1.1 ${ }^{2}$ Ibid Part VIII, B 1.1.1

${ }^{3}$ Musa Ibrahim and Kasim Imam, 'Overview of Environmental Laws, Regulations, And Multilateral Environmental Agreements in Nigeria' (UNEP Global Training Programme on Environmental Law \& Policy

5 th - 13th October 2015 Nairobi, Kenya)

4 Orji, Uchenna Jerome, 'An appraisal of the legal frameworks for the control of environmental pollution in Nigeria'[2012] 38(2)Commonwealth Law Bulletin 321, 329

${ }^{5}$ Oil in Navigable Waters Act - CAP. O6 L.F.N. 1968, section 6

${ }^{6}$ Section 6(3) of National Oil Spills Detection and Response Act Act provides that refusal to clean up an impacted site of an oil spills attract the sum of N1,000, $000(£ 2,000)$; Section 7 (5) a of Oil Navigation Act provides that Failure to comply with the provision of the Oil Navigation Act attracts a fine of N1, $000(£ 2)$; section 26 of Oil Pipelines Regulation provides that failure to comply with the regulation attract fine of N500, 000 (£1000) or an imprisonment term of six months; section 45 (1) and (2) of Petroleum Refining Regulation provides that Failure of any operator to comply with this regulation is 'liable on conviction to a fine of N100 (p 50) or imprisonment for a term of six months ; see also, The Associated Gas Re-Injection ActCap 26 LFN 1990; Cap A. 25 LFN 2004; see also, section 1 The Associated Gas ReInjection (Continued Flaring of Gas) RegulationsSI 43 of 1984, Cap A25 LFN 2004

${ }^{7}$ Oil Pollution Act 33 U.S.C. $\$ 2701$ et seq. (1990) see section 3 Part I

${ }^{8}$ Ibid Section 1004

${ }^{9}$ Section 6(3) National Oil Spill Detection and Response Agency, (Establishment) Act, 2006

${ }^{10}$ Section 12 (1-6) Oil in Navigable Waters Act - CAP. O6 L.F.N. 1968

${ }^{11}$ Ibid

${ }^{12}$ Nigeria National Petroleum Corporation>http://www.nnpcgroup.com/> assessed 23 August 2016

${ }^{13}$ Environmental Assessment of Ogoniland' (United Nation Environmental Programme 2011) (n-3) 35
} 
Nigerian government to either clean up or compensate the affected communities was the sole reason the Centre for Oil Pollution Watch (COP) - a Non-Governmental Organization, brought an action against the Nigeria National Petroleum Corporation to clean up the affected communities. ${ }^{1}$ However, the action brought by Centre for Oil Pollution Watch was not successful as the Appeal Court held that Centre for Oil Pollution Watch lacks jurisdiction. ${ }^{2}$ The truth is that the substantive laws especially the Oil Navigation Act which vests enforcement on the Attorney General of the Federation should be extended to the public. As Orji rightly said, the deficiency in the Oil Navigation Act will hinder public enforcement of the law. ${ }^{3}$

\section{The Environmental Guidelines and Standards for the Petroleum Industry in Nigeria (EGASPIN)}

EGASPIN is the most significant document or standards which ensure that the operators do not degrade the environment in the course of their operation. ${ }^{4}$ This guideline was initiated since 1981, and it was issued in 1996. After six years of existence, the guidelines were revised in 2002. ${ }^{5}$ The 2002, guidelines are the extant standards for the operators to follow and ensure good practices. Presently, the 2002 guidelines are undergoing an amendment. $^{6}$

EGASPIN is a huge document that runs into 415 pages with eight parts, it is quite difficult to read due to size and pollution-related terminologies. But the document contains good practices which are intended to avoid pollution, ranging from 'petroleum exploration to production and processing operations'. ${ }^{7}$ For instance, EGASPIN direct that seismic operation should be undertaken only by qualified and competent persons and the operators should notify the Department Petroleum Resources of the competency of such persons. ${ }^{8}$ It also directs that oil spillages and leakages of pipelines should be reported. ${ }^{9}$ EGASPIN stipulates various means of controlling Oil pollution from pipeline operation, it stipulates that operators should carry out appropriate hazard assessment before pipelines are laid. All materials should be carefully inspected for manufacturing defects, welded joints should be carefully inspected and tested to identify 'wall cracks, thin holes, or other defects that might cause leakage. ${ }^{10}$ In fact, Stakeholder Democracy Network argued that the provision of EGASPIN is of international standards. ${ }^{11}$ Despite the fact that the document is quite fantastic the following areas of the document need to be strengthened.

\subsection{Shifting of Inspection Role to Operators}

To prevent oil spill incident, EGASPIN imposed an obligation on the Oil Corporations to patrol and inspect oil facilities in every month. ${ }^{12}$ This is so important because routine inspection could lead to an identification of rusty pipes and other factors that could lead to an oil spill disaster.

However, the challenge of imposing the obligation of patrolling and inspection on the Oil Corporations is that it will make the regulator take its eyes off the ball. ${ }^{13}$ It will make the regulator sit and relax and expect the operators to comply and perform magic. But this is not the case because the primary motive of the operators is to make profit and as such, they will be more relaxed to effect repairs and change facilities as at when due if the regulators are not on the ground. This is the case in the Niger Delta where huge number of spills were recorded as a result of corrosion, that is, rusty pipes which are overdue for replacement. ${ }^{14}$

Most countries including the USA where effective regulation in the oil industry is recorded, the power of inspection is exclusively reserved for the regulator. For instance, the Bureau of Safety and Environmental Enforcement (BSEE) $)^{15}$ of the USA which one of the primary duties is to enforce compliance has 55 inspectors, and they conduct not less than a thousand inspections in a year. ${ }^{16}$ This is also the case in the United Kingdom

\footnotetext{
${ }^{1}$ Centre for Pollution Watch V Nigeria National Petroleum Corporation (2013) LPELR-20075(CA), 10

2 Ibid 31

${ }^{3}$ Orji, Uchenna Jerome (n-56) 329

${ }^{4}$ Prof. Jubril Aminu, 'Honourable Minister of Petroleum Resources' (EGASPIN Revised Edition 2002) see Forward

${ }^{5}$ Ibid

${ }^{6}$ Ibid

${ }^{7}$ EGASPIN 2002 see forward

${ }^{8}$ Ibid Part II D 1.1 .2

${ }^{9}$ Ibid Part VI A 2.0.

${ }^{10}$ Ibid Part VI D 1.1; see also Part III E 3.6.4.1.

11 C Gragg, J Groft, I Samiami 'Environmental Regulation and Pollution Control in the Global Oil Industry in Relation to Reform in Nigeria (Stakeholder Democracy Network 2014), $9<\mathrm{http}$ ://www.stakeholderdemocracy.org/sdn-report-environmental-regulation-and-pollutioncontrol-in-relation-to-reform-in-nigeria/> 27 July 2016

12 EGASPIN Part VI, E, 3.2.1

${ }^{13}$ C Gragg, J Groft, I Samiami 'Environmental Regulation and Pollution Control in the Global Oil Industry in Relation to Reform in Nigeria $(\mathrm{n}-76)$

${ }^{14}$ Ibid 11

${ }^{15}$ Bureau of Safety and Environmental Enforcement $<$ https://www.bsee.gov/> accessed 18 August 2016

${ }^{16} \mathrm{C}$ Gragg, J Groft, I Samiami 'Environmental Regulation and Pollution Control in the Global Oil Industry in Relation to Reform in Nigeria (n-76) 34
} 
(UK) where Offshore Environmental Inspectorate (OEI) was reportedly 'made over 50 inspections a year.'

The truth is that when regulators are responsible for inspection what might have overlooked by the operators will be put into a total scrutiny and if a fault is found the operator's attention will be drawn. This could save major oil disasters that would affect the environment. Therefore, Part VI, E, 3.2.1 of EGASPIN which imposed monthly inspection on the operators needs to be considered.

\subsection{The 24 Hours Clean Up Mandate}

Part VIII, B, 2.6.3 of EGASPIN is to the effect that whenever there is an oil spill, the polluter is to commence clean-up exercise '.. within 24 hours of the occurrence of the spill...'

In relation to the 24 hours clean up mandate, it has been said repeatedly that carrying out clean-up exercise within 24 hours is not possible ${ }^{3}$ and this has been the position of the Oil Corporations. Since the commencement of EGASPIN, the 24-hour instruction has never been enforced. ${ }^{4}$ At best the 24-hour mandate to clean up is just there to add to the pages of EGASPIN. To this end, it is needful for the regulator that is, the Department of Petroleum Resources and the Oil Corporations to write rules that are realistic.

\subsection{The Legal Status of EGASPIN}

The binding status of the provision of EGASPIN on the operators is being questioned. ${ }^{5}$ This is quite important because a document like EGASPIN which provides the minimum standards required by the operators to comply so as to avoid pollution must be legally binding.

EGASPIN was made and issued by the Department of Petroleum Resources. ${ }^{6}$ The Department of Petroleum Resources is an agency in the Ministry of Petroleum Resources which primary mandate is to increase oil production in Nigeria. ${ }^{7}$ The argument is that there is no specific Act of parliament empowering the Department of Petroleum Resources to make regulations neither the functions outlined on the web page of the Department of Petroleum Resources specifically directs the Department of Petroleum Resources to issue standards on the operators. However, it is debatable that the Department of Petroleum Resources which function is to supervise and monitor the Oil Corporation to comply with the laws can issue rules to fill gaps that are not provided for by an Act of parliament.

These standards though undergoing an amendment but were in existence for more than nine years and they were never being challenged by the operators including Shell Petroleum Development Corporation (Shell). This investigation shows that operators including Shell recognised standards contained in EGASPIN, such as the $500 \mathrm{kmg} / \mathrm{kg}$ TPH threshold for effective remediation. Shell had purportedly used this threshold in many spill remediation exercises. ${ }^{8}$ Though, it was criticized by Amnesty International that Shell did not follow the required threshold. ${ }^{9}$

Again, Shell obligation to patrol and monitor pipelines imposed by EGASPIN to prevent spill was reportedly being complied with. ${ }^{10}$ According to Shell, they had embarked on maintaining and replacing pipelines. ${ }^{11}$ In 2015, "Forty-two kilometres $(\mathrm{km})$ of flow lines and $12 \mathrm{~km}$ of pipelines were maintained and replaced'. ${ }^{12}$ For the last four years, $900 \mathrm{~km}$ has been installed. ${ }^{13}$ Apart from this, they have been conducting a regular flight to detect spill especially vandals, they have signed a Global Memorandum of Understanding $(\mathrm{GMoU})$ with the communities and funds are made available to unarmed youths to patrol pipelines to report theft and oil spill incidents. ${ }^{14}$ But what has never been recorded is the success of Shell measures as the record in 2015 shows that pollution has doubled. ${ }^{15}$

The truth is that the legal status or the binding effect of EGASPIN on the operators is not a major problem,

\footnotetext{
${ }^{1}$ Ibid 34

${ }^{2}$ Ibid Part VIII, B, 2.6.3; section 6(2) National Oil Spill Detection and Response Agency, (Establishment) Act, 2006

${ }^{3}$ Ibid 8

${ }^{4}$ Ibid

${ }^{5} \mathrm{C}$ Gragg, J Groft, I Samiami 'Environmental Regulation and Pollution Control in the Global Oil Industry in Relation to Reform in Nigeria (n-76) 39; see also Environmental Assessment of Ogoniland' (United Nation Environmental Programme 2011) (n-3) 144

6 'Petroleum Regulatory Agency in Nigeria (Department of Petroleum Resources) < https://dpr.gov.ng/index/> accessed 5 August 2016

${ }^{7}$ See the mandate of Ministry of Petroleum Resources <http://petroleumresources.gov.ng/index.php/about-us/mission-vision-mandate> accessed 6 April 2019

${ }^{8}$ Shell Petroleum Development Company of Nigeria (SPDC) $<$ http://www.shell.com.ng/aboutshell/our-business/bus-nigeria/e-andp/spdc.html > accessed August 19 2016; see also Environmental Assessment of Ogoniland' (United Nation Environmental Programme 2011) (n-3) 155

${ }^{9}$ Bad Information - Oil Spill Investigation in the Niger Delta' (Amnesty International, 2013) 20

10 'Shell in Nigeria Security, Theft, Sabotage and Spills' (Shell Nigeria 2015) http://s04.static-shell.com/content/dam/shellnew/local/country/nga/downloads/pdf/security-theft-em.pdf

${ }^{11}$ Ibid

${ }^{12} \mathrm{Ibid}$

13 ibid

${ }^{14}$ Ibid

${ }^{15}$ Ibid
} 
what is needed to be done is for the regulating agencies to be on the ground to ensure that the operators comply with the provisions of EGASPIN.

\subsection{The Petroleum Industry Bill and the Status of EGASPIN}

The Petroleum Industry Bill is a new bill proposed by the National Assembly to establish a new legal frame work for the purpose of regulating the Petroleum Industry in Nigeria. ${ }^{1}$ The Department of Petroleum Resources would be abolished if the Petroleum Industry Bill is passed into law. The first part of the Petroleum Industry Bill under section 4(3) abolishes and transfers the assets and the functions of Department of Petroleum Resources to a new commission called Nigeria Petroleum Regulatory Commission (NPRC) created by the Bill. ${ }^{2}$ The point is that the NPRC will enjoy legal backing from the Nigerian parliament as opposed to the Department of Petroleum Resources. The implication is that the argument of the legal backing of EGASPIN will be laid to rest once the Petroleum Industry Bill commences.

5.5 The Dual Roles of Reporting Imposed on the Operators

Both the National Oil Spills Detection and Response Act and the EGASPIN impose an obligation on the operators to report oil spill incident. For instance, section 6(2) of the National Oil Spills Detection and Response Act is to the effect that an oil spiller is under an obligation to report oil spill within 24 hours in writing to the National Oil Spills Detection and Response Agency. ${ }^{3}$

A Similar provision is contained in the EGASPIN where it directs polluters to report oil spill incidents to the Department of Petroleum Resources. ${ }^{4}$ The issue is that it is not proper to direct the operators to report oil spill incidents to the National Oil Spills Detection and Response Agency at one hand and to the Department of Petroleum Resources on the other hand. This could confuse the operators as to who to report oil spill incident first. Not only that, it could amount to dual reporting by the operators. ${ }^{5}$

\section{Restriction Imposed by the Laws on the Public}

The Environmental Impact Assessment and Freedom of Information Acts play a key role in protecting the environment by allowing citizen participation in the activities that will affect them. For instance, the Environmental Impact Assessment Act gives an opportunity to the public including an expert and interested groups to participate in the process of environmental assessment activities. ${ }^{6}$ Similarly, the Freedom of Information Act gives right to the public to access any information in any government institutions. ${ }^{7}$

Although the Environmental Impact Assessment and Freedom of Information Acts help citizens to participate and access information in order to enforce and implement environmental unfriendly activities, the following aspects of these laws need to be reconsidered.

First, the Environmental Impact Assessment Act states that the process of allowing the public to participate in environmental assessment is an opportunity. ${ }^{8}$ In the wording of section 7 of the Environmental Impact Assessment Act states that 'Before the Agency gives a decision on an activity .... the Agency shall give an opportunity to ... members of the public....? 9 An opportunity is a chance. ${ }^{10}$ The process of the public to participate in environmental impact assessment is a right, not an opportunity. ${ }^{11}$ The implication of the language of the above section is that it makes public participation in environmental assessment activities subject to the discretion of the authority. If the authority decides not to allow public participation, they are exonerated since it is an opportunity.

The Freedom of Information Act in section 1 specifically mentioned government institutions, officials and agency to allow the public to access information but it fails to mention private corporations to provide information on oil spill, emissions and pollution. This means that private corporations are shielded from the public to access information. This failure to mention private corporations played out recently where Nigeria National Petroleum Corporation, though, a government corporation, deliberately denied disclosing information

\footnotetext{
${ }^{1}$ The Petroleum Industry Bill 2012, (Federal Republic of Nigeria National House of Assembly) < http://www.petroleumindustrybill.com/wpcontent/uploads/2017/05/FINAL-COPY-OF-PETROLEUM-INDUSTRY-GOVERNANCE-BILL-2017-May-15.pdf > assessed 20 August 2019

${ }^{2}$ Section 4(3) of the Petroleum Industry Governance Bill PIGB

${ }^{3}$ See also section $6(1) \mathrm{b}$

${ }^{4}$ Paragraph 5.1.1, 'Spill Prevention and Counter Measures Plan'

${ }^{5}$ Olaniyan, Ayobami, 'The Law and Multi-Agency Response to Oil Spill Incidents in Nigeria' (2015) 9

${ }^{6}$ Environmental Impact Assessment Act sections 7 and 8

${ }^{7}$ Freedom Information Act section 1, section 15 (4)

${ }^{8}$ Section 7 of Environmental Assessment Act

${ }^{9}$ Emphasis added

${ }^{10}$ Oxford Advanced Learner's Dictionary (sixth edn) 890

${ }^{11}$ Guidelines for the development of national legislation on access to information, public participation and access to Justice in environmental matters' (United Nation Environmental Programme 2010) society/Portals/24105/documents/Guidelines/Guidelines_To_Access_To_Env_Info_2.pdf $>$ assessed 8
} 
to Daily Trust Newspaper for journalism purpose. ${ }^{1}$ A letter written by Nigeria National Petroleum Corporation refusing disclosure of information states that 'it was not bound by the Freedom of Information Act, as it was not a statutory corporation.'2

\section{Lack of Power of Review by the Public}

The Environmental Impact Assessment and Freedom of Information Acts though give a participatory opportunity to the public but do not give the right to individual or NGOs to review process in the court. The current trend of enforcement of environmental law is more than mere participation alone or vesting enforcement rights on the Attorney General of the Federation to enforce compliance. It gives a complete three rights, that is, the right to access information, ${ }^{3}$ the right to participate, ${ }^{4}$ and the right to review. ${ }^{5}$

For effective enforcement of the laws to protect the environment the right to review or bring an action must be given to individuals who may likely to be affected by environmental pollution. This right to review is also extended to NGOs by the United Nations Environmental Programme (UNEP) Bali Guidelines which asks countries to implement Principle 10 of Rio. ${ }^{6}$ Guideline 8 specifically gives power to NGOs to be part of the review process.

Contrariwise, in Nigeria, laws that protect the environment ranging from Environmental Impact Assessment and Freedom of Information Acts do not specifically allow individuals especially NGOs to bring an action in court. This is evident in the case of Douglas $V$ Shell. ${ }^{7}$ Here the plaintiff sued Nigeria National Petroleum Corporation, Shell Petroleum Development Corporation, Mobil and the Nigerian Liquefied Natural Gas (NLNG) on the ground that a project jointly executed by these companies did not comply with the Environment Impact Assessment Act. The Federal High Court held that there is no direct injury caused by the project to the plaintiff. ${ }^{8}$ Similar position was reached in the following cases Busari V Oseni, ${ }^{9}$ Shell Pet. Dev. Co. Ltd. V Otoko. ${ }^{10}$ These areas of the laws that is, the Environment Impact Assessment Act which gives the power to participate without power to review or the Oil Navigation Act which empowers the Attorney General of the Federation alone for enforcement is worrisome as this will hamper public enforcement of the law on the operators not to pollute the environment.

\section{The Freedom of Information Act is underutilized by the Public}

The Freedom of Information Act is quite new; it was signed into law in 2011, just four years ago. The truth is that the public is yet to explore its provision to demand environmental information in order to protect the environment. This could be the high level of illiteracy in the country. ${ }^{11}$ Few cases recorded under the Freedom of Information Act is exclusively on human right cases. ${ }^{12}$ About 14 applications filed by The Socio-Economic Rights and Accountability Project (SERAP) contained in the website of R2 $\mathrm{K}^{13}$ seek government Agencies to publish documents relating to government spending. ${ }^{14}$ None of the applications is related to the protection of the environment. Therefore, there is a need to sensitize the Nigerian population to explore the provision of the Freedom Information Act to protect the environment.

${ }^{1}$ Funmilola O Omotayo, 'The Nigeria Freedom of Information Law: Progress, Implementation Challenges and Prospects' [2015] Library Philosophy and Practice 1, 7; see also,

'Nigeria: Oil Swap - Court Fixes Mar 26 for Lawyer's Reply to NNPC' (R2K 2015 ) $<\mathrm{http}$ ///r2knigeria.org/index.php/component/content/article/36-foi-monitoring/184-monitoring-foi-request-in-nigeria $>$ accessed 20 August 2016.

${ }^{2}$ Funmilola O Omotayo, (n 107) 7

${ }^{36}$ Guidelines for the development of national legislation on access to information, public participation and access to Justice in environmental matters' (United Nation Environmental Programme 2010) society/Portals/24105/documents/Guidelines/Guidelines_To_Access_To_Env_Info_2.pdf $>$ assessed 8 September 2016; see Guideline 1

${ }^{4}$ Ibid Guideline 8

${ }^{5}$ Ibid Guideline $15,16,17$ and 18

${ }^{6}$ Ibid

${ }^{7}$ Unreported Suit No.FHC/L/CS/573/96

${ }^{8}$ Ibid paragraph 23

9(1992) 4 NWLR (Pt. 237) 557

${ }^{10}$ (1990) 6 NWLR (Pt.159) 693; see also The Shell Petroleum Development Company Of Nigeria Limited V. Helleluja Fishermen MultiPurpose Co-Operative Society Limited (2001) Lpelr-5168(Ca); Nigerian National Petroleum Corporation (Nnpc) \& Anor V. Chief Stephen Orhiowasele \& Ors(2013) LPELR-20341(SC)

${ }^{11} \mathrm{~J}$ George Frynas, Oil in Nigeria Conflict and Litigation between Oil Companies and Village Communities (First edn, Lit Verlag MunsterHamburg-London 2000) 60

12 I Nnochiri, 'Falana asks court to compel AGF to reveal Gov Suntai's health status' (Vanguared 2013)<http://www.vanguardngr.com/2013/09/falana-asks-court-to-compel-agf-to-reveal-gov-suntais-health-status/> accessed 24 August 2016

13 ، Nigeria Releases Report On the Level of Proactive Disclosure by Public Institutions in Nigeria; Results Disappointing' (R2K) $<$ http://r2knigeria.org/index.php?start=3> accessed 2 September 2016

14 Ibid 


\section{Recommendations}

The above analyses have shown that the substantive laws, regulation are weak, the sanctions imposed on Oil Corporations to comply with the pollution prevention laws are too low, the public is excluded from enforcing the laws to protect the environment. Inspection of oil pipelines is imposed on the operators while the regulators go to sleep expecting miracles to happen. The 24 hours clean up mandate recognised by EGASPIN is unrealistic.

As stated earlier, the EGASPIN is under amendment, this current review of EGASPIN should be done collaboratively between the operators and the regulators to ascertain realistic practice. For instance, the 24-hour clean-up mandates given to the operators should be thoroughly reviewed. ${ }^{1}$

The duty of patrolling and inspection of oil facilities should be taking off from the operators and vest it on the regulators. ${ }^{2}$ It does not necessarily need an amendment of Part VI, E, 3.2.1 of EGASPIN for the Department of Petroleum Resources which is in charge of enforcing the provision of EGASPIN to tour around the facilities and ask the operators to effect repairs when necessary. Again, a special inspection team should be established for this purpose and a routine inspection should be carried out preferably in every week considering the Niger Delta environment where crude oil theft is high. ${ }^{3}$ However, imposing an inspection role on the regulators will make no difference in Nigeria especially where officers are not properly trained, ${ }^{4}$ where there is lack of facilities to convey staff around the oil facilities. ${ }^{5}$

The dual reporting system recognised by both EGASPIN and National Oil Spills Detection and Response Act should be critically investigated. Since EGASPIN is undergoing an amendment Paragraph 5.1.1 should be amended in a way that will allow operators to report an oil spill incident to National Oil Spills Detection and Response Agency alone.

Academics have suggested that the penalties in the Oil Navigation Act and the National Oil Spills Detection and Response Act should be increased ${ }^{6}$ so as to compel Oil Corporation to comply with the laws. There is nothing wrong increasing the penalties, however, the increment of penalties should go along with imposing liability on Oil Corporations to clean up an affected environment by oil spill.

To deal with the issues of Freedom of Information and the Environmental Impact Assessment Acts, the following suggestions are necessary. The duty imposed on the government agencies to disclose information should be extended to private corporations and a sensitization campaign should be carried out by the environmental agencies such as, the Department of Petroleum Resources and National Oil Spills Detection and Response Agency which will enable the citizens to explore the provision of Freedom of Information Act in relation to pollution issues.

The UNEP Guideline 8 be incorporated to allow interested groups and NGOs to bring an action in court to compel operators to comply or the Fundamental Rights Enforcement (Procedure Rules 2009) in Nigeria which allows public interest litigation should be incorporated which will enable the public, including NGOs to file an action in court and protect the environment. ${ }^{7}$ However, extending the right of enforcement to the public does not take away the obstacles of locus standi $i^{8}$ and other technicalities in the court process. ${ }^{9}$ Again, the Bali Guidelines are not binding as the name suggests, it is a mere guideline.

\section{Conclusion}

The Nigerian government through the parliament, ministers had initiated several laws ranging from substantive laws, policies, standards and regulations to protect the environment of Nigeria especially, crude oil pollution. The truth is that these numerous laws failed to protect the environment of Nigeria.

\section{Bibliography \\ Legislation}

- African Charter on Human and Peoples' Rights (Ratification and Enforcement) Act - CAP. A 9 L.F.N. 2004

- Environmental Guidelines and Standards for the Petroleum Industry 2002 Revised

- Environmental Impact Assessment Act CAP. E12 L.F.N. 2004

- Federal Environmental Programme Agency Act CAP. F10 L.F.N. 2004

\footnotetext{
${ }^{1}$ EGASPIN Part VIII, B, 2.6.3; C Gragg, J Groft, I Samiami 'Environmental Regulation and Pollution Control in the Global Oil Industry in Relation to Reform in Nigeria (n-76) 33

${ }^{2} \mathrm{C}$ Gragg, J Groft, I Samiami 'Environmental Regulation and Pollution Control in the Global Oil Industry in Relation to Reform in Nigeria (n-76) 33

${ }^{3}$ Ibid

${ }^{4} \mathrm{O}$. R. Orji, 'A review of the Nigerian petroleum industry and the associated environ mental problem [2001] 21 (1) 11, 15.

${ }^{5}$ Ibid

${ }^{6}$ Orji, Uchenna Jerome (n-56)

${ }^{7}$ Fundamental Rights Enforcement (Procedure Rules 2009) Preamble para 3(e)

${ }^{8}$ This is a principle of law which says a party who brings an action to the court must show sufficient connection to the harm complaint about.

${ }^{9} \mathrm{~J}$ George Frynas, Oil in Nigeria Conflict and Litigation between Oil Companies and Village Communities (First edn, Lit Verlag MunsterHamburg-London 2000) 83
} 
- Freedom of Information Act, 2011

- Fundamental Rights Enforcement (Procedure Rules 2009)

- National Environmental Standards and Regulations, Enforcement Agency (Establishment) Act, 2007

- National Oil Spill Detection and Response Agency, (Establishment) Act, 2006

- Niger Delta Development Commission Act, 2000 CAP. N86 L.F.N. 2004

- Oil and gas pipelines regulation Cap O7 LFN 2004

- Oil in Navigable Waters Act - CAP. O6 L.F.N. 2004

- $\quad$ Oil in the Navigable Waters Regulations 1968 CAP. O6 L.F.N. 2004

- Oil Navigation Act Cap 337 LFN 1990; Cap 06 LFN 2004

- $\quad$ Oil Pipeline Act CAP. O7 L.F.N. 2004

- Oil Pollution Act 33 U.S.C. $\$ 2701$ et seq. (1990) Section 4304

- Organization of African Unity (OAU), African Charter on Human and Peoples' Rights ("Banjul Charter"), 27 June 1981, CAB/LEG/67/3 rev. 5, $21 \quad$ I.L.M. 58 (1982), available at: http://www.refworld.org/docid/3ae6b3630.html [accessed 2 September 2016]

- Petroleum (Drilling and Production Regulations 1969, CAP. P10 L.F.N. 2004

- Petroleum Act Cap 350 LFN 1990, Cap P.10 LFN 200

- Petroleum Act CAP. P10 L.F.N. 2004

- Petroleum Drilling and Production (Amendment) Regulations 1973, CAP. P10 L.F.N. 2004

- Petroleum Industry Governance Bill 2018

- Petroleum Refining Regulation

- Pipeline Act 2004

- The Associated Gas Re-Injection (Continued Flaring of Gas) Regulations SI 43 of 1984, Cap A25 LFN 2004

- The Associated Gas Re-Injection Act Cap 26 LFN 1990; Cap A. 25 LFN 2004

- The National Oil Spill Contingency Plan [NOSCP] (Revised May 2009)

- The Petroleum Industry Bill 2012, (Federal Republic of Nigeria National House of Assembly) < http://www.nassnig.org/ > assessed 20 August 2016

Cases

- Nigerian National Petroleum Corporation (Nnpc) \& Anor V. Chief Stephen Orhiowasele \& Ors (2013) LPELR-20341(SC

- Social and Economic Rights Action Center v. Nigeria

- The Shell Petroleum Development Company of Nigeria Limited V. Helleluja Fishermen Multi-Purpose CoOperative Society Limited (2001) Lpelr-5168(Ca);

Research papers and Books

- 'Clean it Up: Shell's False Claims About Oil Spill Response in the Niger Delta' (Amnesty International 2015) Index N0: AFR 44/2746/2015<https://www.amnesty.nl/sites/default/files/public/clean_it_up_rapport.pdf $>$ accessed 24 July 2016, 20-23

- 'Gas Flaring in Nigeria: A Human Rights, Environmental and Economic Monstrosity' (Friends of the Earth International 2006) <http://www.foei.org/resources/publications/publications-by-subject/climate-justiceenergy-publications/gas-flaring-in-nigeria > accessed 30 July 2016

- 'Improving Oil Spill Response in Nigeria-Comparative Analysis of the Forms, Data and Related Process of the JIV' (Stakeholder Democracy Network 2016)

- 'Nigeria Vision 20:2020' (Federal Ministry of Budget and National Planning 2009) 83 $<$ http://www.nationalplanning.gov.ng/index.php/national-plans/nv20-2020> accessed 26 July 2016

- 'Report of the Vision 2020 National Technical Working Group on Environment and Sustainable Development' (Federal Ministry of Budget and National Planning 2009) 26 $<$ http://www.nationalplanning.gov.ng/index.php/national-plans/nv20-2020> accessed 26 July 2016

- 'Restoring Nigeria's Law to Nigeria's People - One by One' (Centre for

- 'Review of the National Policy on the Environment 1999' (Federal Ministry of Environment 2014) http://environment.gov.ng/index.php/downloads/3-environmental-policies accessed 28 July 2016

- 'Shell in Nigeria Security, Theft, Sabotage and Spills' (Shell Nigeria 2015) http://s04.staticshell.com/content/dam/shell-new/local/country/nga/downloads/pdf/security-theft-em.pdf

- 'The True Tragedy Delays and Failures in Tracking Oil Spills in the Niger Delta' (Amnesty International 2011) Index: AFR 44/018/2011<http://www.amnesty.cz/zakazdoucenu/doc/Niger-Delta-True-TragedyReport.pdf $>$ accessed 24 July 2016

- Annex 9 Comparison Table of Forms Used to Collect Information Before or During JIV, Improving Oil Spill Response in Nigeria-Comparative Analysis of the Forms, Data and Related Process of the JIV' (Stakeholder Democracy Network 2016) < http://www.stakeholderdemocracy.org/improving-oil-spillresponse-in-nigeria-comparative-analysis-of-the-forms-data-and-related-processes-of-the-joint- 
investigation-visit-jiv-and-suggestions-on-how-these-could-be-improved/> accessed 30 July 2016

- 'Bad Information-Oil Spill Investigation in the Niger Delta' (Amnesty International, 2013) Index No: AFR 44/028/2013, $48<$ https:/www.amnesty.org/en/documents/AFR44/028/2013/en> accessed 24 July 2016

- Bureau of Safety and Environmental Enforcement <https://www.bsee.gov/> accessed 18 August 2016

- C Gragg, J Groft, I Samiami 'Environmental Regulation and Pollution Control in the Global Oil Industry in Relation to Reform in Nigeria (Stakeholder Democracy Network 2014), $21<$ http:/www.stakeholderdemocracy.org/sdn-report-environmental-regulation-and-pollution-control-inrelation-to-reform-in-nigeria/> 27 July 2016, 21

- Carleton K Allen, Law in the Making (Oxford: Clarendon Press 1958) 56

- Environmental Assessment of Ogoniland' (United Nation Environmental Programme 2011) 30$35<\mathrm{http}: / /$ www.unep.org/> accessed 12 July 2016

- Fact Sheet: The BSEE and BOEM Separation an Independent Safety, Enforcement and Oversight Mission' (Bureau of Ocean Energy Management 2011)

- Frynas, J.G., 2000. Oil in Nigeria: conflict and litigation between oil companies and village communities (No. 1). LIT Verlag Münster.

- Ibrahim, M and Imam K, 2015 Overview of Environmental Laws, Regulations, And Multilateral Environmental Agreements in Nigeria' (UNEP Global Training Programme on Environmental Law \& Policy 5th - 13th October 2015 Nairobi, Kenya)

- Improving Oil Spill Response in Nigeria-Comparative Analysis of the Forms, Data and Related Process of the JIV' (Stakeholder Democracy Network 2016) $31<\mathrm{http}$ //www.stakeholderdemocracy.org/improvingoil-spill-response-in-nigeria-comparative-analysis-of-the-forms-data-and-related-processes-of-the-jointinvestigation-visit-jiv-and-suggestions-on-how-these-could-be-improved/> accessed 30 July 2016

- Laws of the Federation of Nigeria) <http://lawnigeria.com/FederationlawsN.html > assessed 3 June 2016

- Oil Spill Data 'shell Nigeria' < http://www.shell.com.ng/sustainability/environment/oil-spills.html> accessed 28 June 2016

- Okonta, I. and Douglas, O., 2003. Where vultures feast: Shell, human rights, and oil in the Niger Delta. Verso.

\section{Articles}

- Ajugwo, A.O., 2013. Negative effects of gas flaring: The Nigerian experience. Journal of Environment Pollution and Human Health, 1(1), pp.6-8.

- Rim-Rukeh, A., 2015. Oil spill management in Nigeria: SWOT analysis of the joint investigation visit (JIV) process. Journal of Environmental Protection, 6(03), p.259.

- Emejuru, C.T., 2014. Human Rights and Environment: Whither Nigeria. JL Pol'y \& Globalization, 30, p.19.

- Gragg C, 2016. Environmental Regulation and Pollution Control in the Global Oil Industry in Relation to Reform in Nigeria. SDN <available http://www.stakeholderdemocracy.org/wpcontent/uploads/2016/06/Environmental-Regulation-and-Pollution.pdf $>$ accessed $2^{\text {nd }}$ December 2018

- Omotayo, F.O., 2015. The Nigeria freedom of information law: Progress, implementation challenges and prospects. Library Philosophy and Practice, 12119.

- Eneh, O.C. and Agbazue, V.C., 2011. Protection of Nigeria's environment: A critical policy review. Journal of Environmental Science and Technology, 4(5), pp.490-497.

- Orji, U.J., 2012. An appraisal of the legal frameworks for the control of environmental pollution in Nigeria. Commonwealth Law Bulletin, 38(2), pp.321-346.

- Uyigue, E. and Agho, M., 2007. Coping with climate change and environmental degradation in the Niger Delta of southern Nigeria. Community Research and Development Centre Nigeria (CREDC), 1, p.30. 